\title{
MAPPING OF LAND-COVER CHANGE ANALYSIS IN MA'RIB AT YEMEN USING REMOTE SENSING AND GIS TECHNIQUES
}

\author{
AL-AKAD Sultan ${ }^{1 *}$, AKENSOUS Youness ${ }^{1}$, HAKDAOUI Mustapha ${ }^{1}$, AL-NAHMI Fuad $^{2}$, MAHYOUB \\ Sulaiman $^{2}$, KHANBARI Khaled ${ }^{3}$, SWADI Hassan ${ }^{4}$ \\ ${ }^{1}$ Laboratory of Applied Geology, Geomatics and Environment, Faculty of Sciences ben M'sik, Hassan II University, \\ Casablanca, Morocco (su.sultan12@gmail.com, akensous1990@gmail.com, hakdaoui@gmail.com) \\ 2 Laboratory Geosciences, Department of Geology, Faculty of Sciences, Hassan II University Casablanca, Morocco \\ (geofuad@gmail.com, aldoubai100@gmail.com) \\ 3 Yemen Remote Sensing and GIS Centre, Sana’a UniversityYemen - kkhanbari@hotmail.com \\ 4 Department of Geography and GIS, University of Thi-Gar, Nasiriyah, Iraq - Dr.hassan.swadi@gmail.com
}

KEY WORDS: Ma'rib Yemen, Land-use and land-cover (LULC), Remote sensing, Change detection, LULC map, Non-supervised classification, Recode

\begin{abstract}
:
Studies on the change in occupation and land-use are of great importance in order to understand landscape dynamics in the process of agricultural land degradation, urbanization, desertification, deforestation and all change in the landscape global of a region. The most effective procedure to measure the degree of land-cover and land-use changes is the multi-date study. For this purpose, the aim of this work is to analyze the current evolution of land-use and land-cover (LULC) using remote sensing techniques, in order to better understand this evolution. For this purpose, a diachronic approach is applied to satellite images acquired in 1987 to 2018 of Ma'rib city Yemen. The LULC maps we obtained were produced from different image analysis procedures (non-supervised classification and recode technique) to map the land-use and land-cover. The objective of this study is to apply reproducibly and generalizable a predefined nomenclature to different scenes of satellite images. The first step consists in interpreting the radiometric classes obtained by non-supervised classification so as to form the classes of the thematic nomenclature. An improvement of the classification is then obtained by using the recode technique which makes it possible to correctly reassign the previously badly classified pixels of the satellite images classification. Land-cover maps obtained from remote sensing were used to quantify the rate of change (Tc) and ( $\mathrm{Tg}$ ) of area occupied by each class. The results will indicate the most changeable period and the percentage of overall change in the study area (Ma'rib Yemen), and helped to identify and characterize the spatial and temporal evolution of land use in the district over a period of thirty-one years (1987 to 2018). They reveal that annual average rates of decline for the water body is $-83.5 \%$ and $-9.96 \%$ for the sandy land. However, it was observed an increase in built-up area $365.52 \%$ and farm land $324.52 \%$ classes.
\end{abstract}

\section{INTRODUCTION}

Land-use and land-cover changes in world-wide environmental modifications that can lead to adverse effects (Iqbal and Khan, 2014) .That why the analysis of LULC change is necessary for both scientific and policy actions on cities vulnerability assessment (Brown et al., 1999; Benoit and Lambin, 2000; Ayad, 2004; Baby, 2015).

The LULC change analysis provides a primary information for sustainable Ma'rib city management, therefore, it is very essential for the obtaining the reliable information in order to support proper land resource management planning in the study zone (Weismiller and Momin, 1977; Wu et al., 2002; Zoran, 2006; Zhang and Zhu, 2011; Butt et al., 2015a). Changes in LULC signify environmental changes brought about by natural or anthropogenic consequences (Rawat and Kumar, 2015). The rapid changes of land-use and cover than ever before, particularly in developing nations, are often characterized by rampant urban sprawling, land degradation, ensuing enormous cost to the environment (Sankhala and Singh, 2014). The main drivers of global environmental change and sustainable development are land-use and change in land-cover. Land-use and land-cover change were examined in this work to quantify land-use / land-cover change in the city of Ma'rib in Yemen. This provides an important aspect in evaluating, monitoring and conserving Earth's resources that is required for sustainable development and economic proliferation of an area (Rawat et al., 2013a). It is therefore indispensable to examine the changes in land-use/cover, so that its effect on sustainable land-use planning can be formulated (Muttitanon and Tripathi, 2005).

The advent and development of the integrated geospatial techniques with Remote Sensing (RS) and Geographic

\footnotetext{
* Corresponding author
} 
Information Systems (GIS) the enumeration of spatio-temporal landuse dynamics has become easy, quick,cost-effective and accurate (Rawat and Kumar, 2015). The basic principle of using remote sensing data for growth monitoring is the process of determining and / or describing changes in the properties of the land-cover, which identifies the change between two or more dates (data multi-temporal remote sensing) which is not characteristic of normal variation. Many researchers have addressed the problem of accurately monitoring changes in land-cover and land-use in a wide variety of environments (Shalaby and Tateishi, 2007). Digital image processing on multi-temporal multi-spectral satellite imagery has great potential in LULC categorization, landscape dynamics and change detection analyses. The changes in land-use and landcover due to various physical, climatic factors are directly influencing the socio-economic status of local people along the Ma'rib in space and time. Usually the LULC change in remote sensing involves the analysis of two registered, aerial or satellite multispectral bands from the same geographical area obtained at two different times. Such an analysis aims at identifying changes that have occurred in the same geographical area between the two times considered (Radke et al., 2005). Satellite remote sensing is a potentially powerful means of monitoring land-use change at high temporal resolution and lower costs than those associated with the use of traditional methods (ElRaey et al., 1995). The growth of population, urbanization and agricultural and other activities are altering the existing state of landuse and land-cover features (Clark, 1982; Jaiswal et al., 1999; Chilar, 2000; Yuan et al., 2005; Joshi et al., 2011; Rawat et al., 2013).

The land-use changes without considering environmental sustainability is increasing the demand for land resources like agriculture, minerals, soil and water (Gibson and Power, 2000; Lu et al., 2004; Zoran, 2006; Santhiya et al.,2010). Nowadays, the rate of demand is higher than the rate that the land can sustainably provide in water and land resources, which causes more serious long-term sustainability problems around the world (Xiuwan, 2002). In Yemen, Ma'rib, the construction of a dam and population growth are the principal facts about changes in the city's environment.

Global assessment of percentage of land-cover affected by human action vary from $20 \%$ to $100 \%$, whereas, the humans appropriate $20 \%$ to $40 \%$ of the earth's potential net primary biological production (Richards, 1990; Nemani and Running, 1995; Brown et al., 1999; Small and Nicholls, 2003). Increasing of population and climatic variability produces changements on the landuse and land-cover (LULC) causing the greatest environmental impact on vegetative cover, shoreline change, landform (Chandrasekar et al., 2001; Chauhan and Nayak, 2005; INCOIS, 2009; Mahapatra et al., 2013; Kaliraj et al., 2014).

The integrated remote sensing and GIS techniques provide the successful platform for mapping the LULC features as per user requirement (Jaiswal et al., 1999; Chandrasekar et al., 2000; Yagoub and Kolan, 2006; Kawakubo et al., 2011; Misra et al., 2013; Rawat and Kumar, 2015). In the conventional methods, the mapping of LULC features is performed using available records, maps and field survey. It is often time consuming process, exhaustive and expensive and the output maps soon become outdated with the passage of time particularly in the rapidly changing environment (Anderson et al., 1976; Wickware and Howarth, 1981; Singh, 1989; Nemani and Running, 1995; Nayak, 2002; Wang et al., 2004, 2008; Rawat et al., 2013). Satellite image provides a synoptic coverage of the earth surface in spatial and temporal scale helps to understand the changes happened in various parts of the environment. (Misra et al., 2013). Integrated GIS and remote sensing technique deals with the spatio-temporal information of LULC features and well recognized for decision making in the scientific realm (Rawat et al., 2013; Misra and Balaji, 2015). The GIS and remote sensing combines the multiple spatial datasets such as maps, aerial photographs, and satellite images for preparing the quantitative, qualitative and descriptive geodatabases for periodical changes of the LULC features. Many researchers have stated that the remote sensing techniques for LULC change detection analysis in local, regional and global scales (Wickware and Howarth, 1981; Avery and Berlin, 1992; Jaiswal et al., 1999; Chandrasekar et al., 2000; Alam et al., 2002; Jayappa et al., 2006; Santhiya et al., 2010; Mujabar and Chandrasekar, 2012). Landsat and Sentinel-2 images are used worldwide for LULC change detection analysis (Baby, 2015). The advantage of Landsat and Sentinel-2 images with adequate spectral properties provide better information on LULC changes compared to point data collected by on-site instruments during in-situ survey (USGS, 2004; Muttitanon and Tripathi, 2005; Kawakubo et al., 2011). Many researchers have stated the use of Landsat and Sentinel-2 images LULC change analysis (Toll, 1985; Vogelmann et al.,1998; Dwivedi et al., 2005; Akbari et al., 2006; Dewidar and Frihy, 2010; Hereher,2011).

Recently developed algorithms and techniques and software provide relatively accurate information on change detection and transformations of LULC features in the area of interest (Richards and Jia, 2006; Amin and Fazal, 2012; Mohammady et al., 2015). Using nonsupervised classification technique and recorde technic, on the Landsat and Sentinel-2 images provides relatively accurate result in change detection assessment. The present study delivers the trends in landuse and land-cover changes and transformation in the Ma'rib city.

\section{OBJECTIVE}

Digital image processing on multi-temporal, multi-spectral satellite imagery has great potential in LULC categorization, landscape dynamics and change detection analyses. we are Using non-supervised classification technique and recorde technic, on the Landsat and Sentinel-2 images to provide relatively accurate result in change detection assessment. The present study delivers the trends in land-use and land-cover changes and transformation in the Ma'rib city.

\section{STUDY AREA}

The oasis of Ma'rib is located in the central part of the republic of Yemen (Located between latitude and longitude at: 15. 47, long: 45. 3229 III N 15 28'12", E 45 19'22), and is about 173 kilometres away from the capital Sana'a. Situated at the southwestern margin of the Ar-Rub' Al-Khali named Ramlat asSab'atayn (Fig. 1). The region is influenced by the Indian Summer Monsoon (ISM) and the North Easterly circulation in the winter months; the images on (Fig. 2) show the different landscapes of the study area. The desert margin receives very limited moisture twice a year, in the form of ISM rains, reduced by lee effects caused by the Yemen Highlands, and in the form of slight precipitation brought by the North Easterlies in winter. The present climate in Ma'rib has a mean annual precipitation of $<100 \mathrm{~mm}$, an evaporation of $>1800 \mathrm{~mm}$ and mean temperatures of $28^{\circ} \mathrm{C}$ (Bruggemann, 1997). 


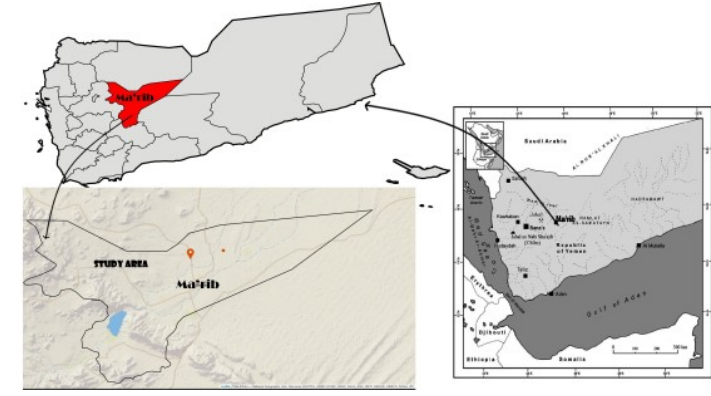

Fig. 1

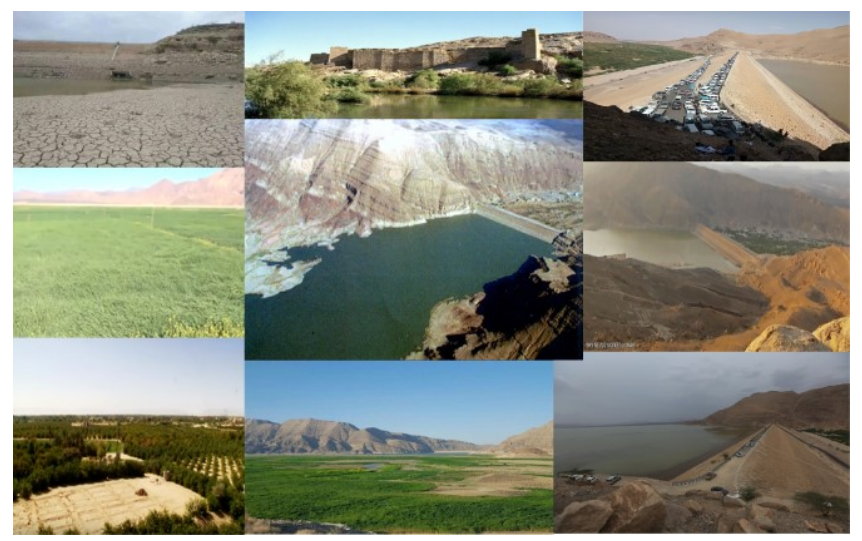

Fig. 2

\section{DATA AND METHODOLOGIES}

The data used in this study include Landsat images, including a Thematic Mapper (TM) image acquired on 11 September, 1987 and Enhanced Thematic Mapper Plus (ETM+) images acquired 2001, in 2011, and Sentinel-2 image on 2018(Fig.3). These time series of Landsat and Sentinel-2 images were acquired during the growing seasons and are freely available from the Landsat archive from the United States Geological Survey (USGS) (http://glovis.usgs.gov) (http://edcsns17.cr.usgs.gov). All visible and infrared bands (except for the thermal infrared band) were included in the analysis. Archived data and old sketch maps (which we scanned and geometrically registered) that were related to the rural urban planning and land reclamation processes in the study area were collected from the Department of Urban Planning and Rural Development in Ma'rib, as well as from governmental agricultural associations.

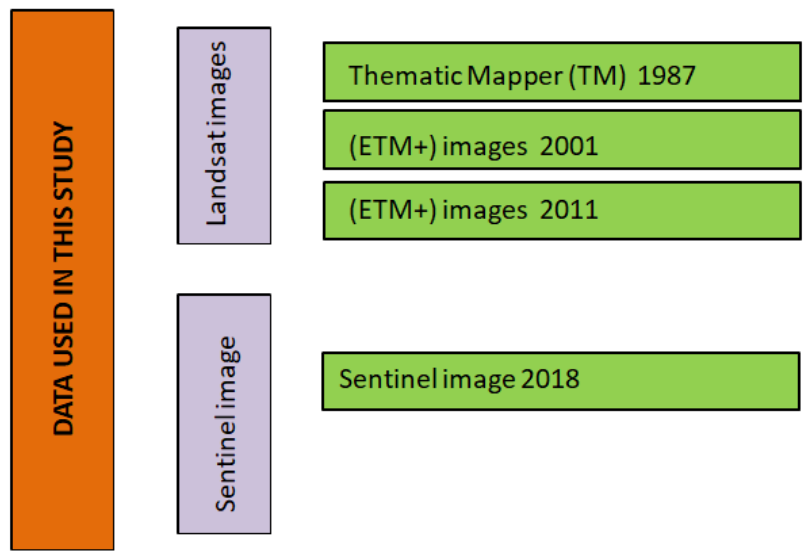

Fig.3: Flow charts of the data for land use/land cover and change detection.

\subsection{Methods}

The methods used in this research include all the ones represented in methodology flowchart (fig.4).

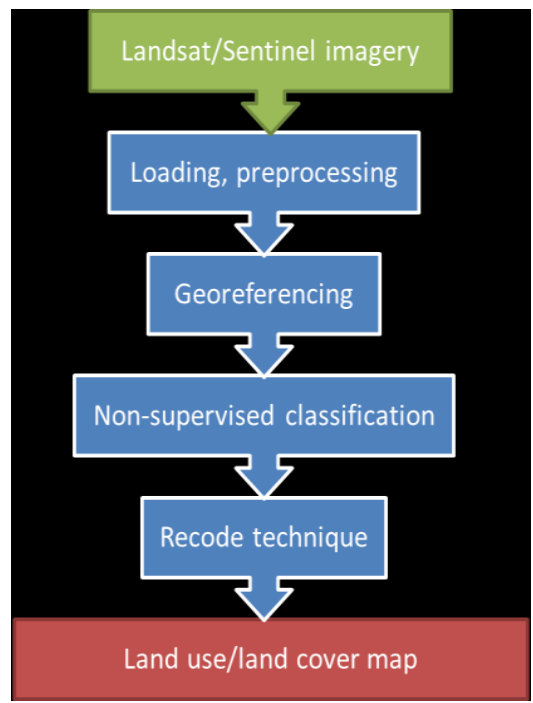

Fig.4: Flowchart of methodology for land-use/land-cover and change detection.

\subsubsection{Image pre-processing}

Pre-processing of satellite images prior to change detection is essential and has the unique goal of establishing a more direct linkage between the data and biophysical phenomena (Coppin et al., 2004). The methodology adopted for this study took into consideration various image pre-processing operations, including geometric correction. All Landsat data used in this study were acquired under clear atmospheric conditions. The 1987 and 2001 images were geometrically corrected to the 2011 image using the root mean square error (RMSE) $<0.5$ pixel. The 2011 image had previously been georeferenced. Whereas geometric correction is generally required in digital change detection, PCC does not require that the images be radiometrically corrected or normalized before they are used for change detection (Warner \& Campagna, 2009).

\subsubsection{Non-Supervised classification}

Before land cover classification, a 4-class classification system was designed with consideration of the land use properties of the study area as urban/built-up, crop field/farmland, water body, sandy lands. The widely used non-supervised classification method was employed to detect the land cover, but in the supervised classification, the overlapping classes pushed us to do some manual work with the recode process. So that the non supervised classification is better than other classifications.

\subsubsection{Classification improvement}

Some LULC classes were spectrally confused and could not be separated well by classification. For instance, the urban class was overestimated in the initial LULC maps produced. This problem was due to the fact that approximately $85 \%$ of the irrigation network system in the study area is constructed from 
concrete materials, which are the same materials, used for building construction. Throughout the study area, anthropogenic activities have had an obvious effect. Finally, in areas consisting of free water bodies, significant numbers of pixels were misclassified to the agriculture class due to the existence of plants. To improve classification accuracy and reduce misclassifications, we integrated the initial LULC maps resulting from classification with the maps resulting from visual interpretation. The recode process using ArcGIS was necessary for the initial LULC maps for the production of LULC maps , which we compared with the reference data (the archived data, old sketch maps, topographic maps, and ground truth points) to assess classification accuracy.

\subsubsection{Change detection}

The spatio-temporal evolution of each land-use class has been evaluated through a series of additional transformations. The relationship between the same class at two different dates made it possible to extract the category of this one, whether it is "stable", "regression" or "progression".

It is assumed that $\mathrm{S} 1$ represents the area occupied by the land cover classes at date 1 and that $\mathrm{S} 2$ is the area of the same classes for date 2 .

In order to quantify changes in land-use classes, several statistical indicators have been calculated; these are the change rates and the transition matrix. Calculation of annual (evolution) change rates( $\mathrm{Tc})$ and overall change rates( $\mathrm{Tg}$ ) between 1987 and 2018 were determined by the equation proposed, by FAO's. (1996) and Bernier's (1992).

$\mathrm{T}_{\mathrm{g}}=\frac{\mathrm{S}_{2}+\mathrm{S}_{1}}{\mathrm{~S}_{1}} \times 100 \quad \mathrm{~T}_{\mathrm{c}}=\frac{\ln \left(\mathrm{S}_{2}\right)-\ln \left(\mathrm{S}_{1}\right)}{\left(\mathrm{t}_{2}-\mathrm{t}_{1}\right) \times \ln (\mathrm{e})} \times 100$

Positive values represent an increase in class area during the period analyzed, while negative values indicate the loss of class area between the two dates. As for the values close to zero, they express a relative stability of the class the two periods.

Transition matrix makes it possible to highlight summarize the different forms of conversion experienced by the units of occupation of land between two dates $\mathrm{t} 1$ and $\mathrm{t} 2$, and describe the changes that have occurred.

\section{RESULTS AND DISCUSSION}

In order to evaluate the landscape change in the time period time between 1987 to 2018, the satellite images were used for land use/land cover classification as described earlier, and the land use and land cover change were then detected and analyzed. Four major land use classes were identified and mapped from different dates of satellite imageries to determine the changes and transformation (position and rate). These classes are: (1) Water body, (2) farmland or cultivated lands, (3) build-up-area (4) sandy land. The analysis that we carried out is based on the detection of the four classes as well as the change of the classes during the period also detection of the change of each class toward another. Then we can quantify the percentage change in the different periods from 1987 to 2018 as well as the overall change throughout the study period. The information of LULC changes and transformation is an essential source for Ma'rib city vulnerability assessment and resources management in the city especially the dam, which represents the essential water resource of the city.

\subsection{Assessment of land use and land cover change and} Landuse, land cover transformation between 1987 and 2001

Fig. 4 shows the spatial distribution of the major landuse and land cover change and transformation in the study area for the year 1987 and 2001. The areal land use land cover transformation of these LULC features in percent and the $\mathrm{T}_{\mathrm{g}}, \mathrm{T}_{\mathrm{c}}$ for the two different periods is shown in Table 1.

\subsubsection{Water body}

the water body of the study area converted to farmland represents $0.31 \%$ and $0.69 \%$ to sandy land of the territory water body along the study area; which was significantly reduced by $-37.45 \%$ in 2001 . However, this withdrawal represents $-3.35 \%$ of the study area; however, this indicates a loss of water areas in this period. This apparent loss was mainly due to aquaculture activities and lack of rain.

\subsubsection{Farmland}

The farmland of the study area converted to built-up land represents $0.049 \%$ and $0.92 \%$ to sandy land of the territory of farmland along the study area; which was significantly advanced by $174.83 \%$ in 2001 . However, this expansion represents $7.22 \%$ of the study area; however, this indicates an advancement of farmland areas in this period.

\subsubsection{Sandy land}

the sandy land of the study area converted to waterbody represents $0.011 \%$ and $0.31 \%$ to built-up, and $6.16 \%$ to farmland of the territory sandy land along the study area; which was significantly reduced by $-4.97 \%$ in 2001 . However, this withdrawal represents $-0.36 \%$ of the study area; however, this indicates a loss of sandy land areas in this period.

\subsubsection{Built-up}

The built-up of the study area converted to farmland represents $0.042 \%$ and $0.206 \%$ to sandy land, of the territory built-up along the study area; which was significantly advanced by $33.74 \%$ in 2001 . However, this expansion represents $2.07 \%$ of the built-up area; however, this indicates an advancement of built-up areas in this period.

5.2 Assessment of land use and land cover change and Landuse, land cover transformation between 2001 and 2011

Fig. 5 shows the spatial distribution of the major landuse and land cover change and transformation in the study area for the year 2001 and 2011. The areal land use land cover transformation of these LULC features in percent and the $\mathrm{T}_{\mathrm{g}}, \mathrm{T}_{c}$ for the two different periods is shown in Table 2 . 


\subsubsection{Water body}

The water body of the study area converted to farmland represents $0,56 \%$ and $0.71 \%$ to sandy land, and $0.00041 \%$ to built-up area of the territory water body along the study area; which was significantly reduced by $-74.33 \%$ in 2011 . However, this withdrawal represents $-7.34 \%$ of the study area; however, this indicates a loss of water areas in this period. This apparent loss was mainly due to aquaculture activities.

\subsubsection{Farmland}

The farmland of the study area converted to built-up land represents $0.049 \%$ and $0.92 \%$ to sandy land of the territory of farmland along the study area; which was significantly advanced by $174.83 \%$ in 2011 . However, this expansion represents $7.22 \%$ of the study area; however, this indicates an advancement of farmland areas in this period.

\subsubsection{Sandy land}

The sandy land of the study area converted to waterbody represents $0.032 \%$ and $0.86 \%$ to built-up, and $5.018 \%$ to farmland of the territory sandy land along the study area; which was significantly reduced by $-0.94 \%$ in 2011 . However, this withdrawal represents $-0.09 \%$ of the study area; however, this indicates a loss of sandy land areas in this period.

\subsubsection{Built-up}

The built-up of the study area converted to farmland represents $0.097 \%$ and $0.22 \%$ to sandy land, and $0.00053 \%$ to waterbody of the territory built-up along the study area; which was significantly advanced by $159.62 \%$ in 2011 . However, this expansion represents $9.4 \%$ of the built-up area; however, this indicates an advancement of built-up areas in this period.

\subsection{Assessment of land use and land cover change and} Landuse, land cover transformation between 2011 and 2018

Fig. 6 shows the spatial distribution of the major landuse and land cover change and transformation in the study area for the year 2011 and 2018. The areal land use land cover transformation of these LULC features in percent and the $\mathrm{T}_{\mathrm{g}}, \mathrm{T}_{c}$ for the two different periods is shown in Table 3 .

\subsubsection{Water body}

The water body of the study area converted to sandy land represents $0.00098 \%$ of the territory water body along the study area; which was significantly reduced by $-0.07 \%$ in 2018 . However, this withdrawal represents $-0.01 \%$ of the study area; however, this indicates a loss of water areas in this period. This apparent loss was mainly due to aquaculture activities.

\subsubsection{Farmland}

The farmland of the study area converted represents $0.0 \%$ of the territory of farmland along the study area; which was significantly advanced by $33.82 \%$ in 2018 . However, this expansion represents $4.16 \%$ of the study area; however, this indicates an advancement of farmland areas in this period.

\subsubsection{Sandy land}

The sandy land of the study area converted to waterbody represents $0.00068 \%$ and $0.701 \%$ to built-up, and $3.41 \%$ to farmland of the territory sandy land along the study area; which was significantly reduced by $-4.32 \%$ in 2018 . However, this withdrawal represents $-0.63 \%$ of the study area; however, this indicates a loss of sandy land areas in this period.

\subsubsection{Built-up}

The built-up of the study area converted to sandy land represents $0.28 \%$ of the territory built-up along the study area; which was significantly advanced by $34.08 \%$ in 2018 . However, this expansion represents $4.19 \%$ of the built-up area; however, this indicates an advancement of built-up areas in this period.

\subsection{Assessment of land use and land cover change and} Landuse, land cover transformation between 1987 and 2018

Fig. 7 shows the spatial distribution of the major landuse and land cover change and transformation in the study area for the year 1987 and 2018. The areal land use land cover transformation of these LULC features in percent and the $\mathrm{T}_{\mathrm{g}}, \mathrm{T}_{\mathrm{c}}$ for the two different periods is shown in Table 4 .

\subsubsection{Water body}

The water body of the study area converted to farmland represents $0.928 \%$ and $1.43 \%$ to sandy land, and $0.0014 \%$ to built-up area of the territory water body along the study area; which was significantly reduced by $-83.95 \%$ in 2018 . However, this withdrawal represents $-5.90 \%$ of the study area; however, this indicates a loss of water areas in this period. This apparent loss was mainly due to aquaculture activities.

\subsubsection{Farmland}

The farmland of the study area converted to built-up land represents $0.0991 \%$ and $0.99 \%$ to sandy land of the territory of farmland along the study area; which was significantly advanced by $324.52 \%$ in 2018 . However, this expansion represents $4.66 \%$ of the study area; however, this indicates an advancement of farmland areas in this period.

\subsubsection{Sandy land}

The sandy land of the study area converted to waterbody represents $0.033 \%$ and $1.37 \%$ to built-up, and $10.41 \%$ to farmland of the territory sandy land along the study area; which was significantly reduced by $-9.96 \%$ in 2018 . However, this withdrawal represents $-0.33 \%$ of the study area; however, this indicates a loss of sandy land areas in this period.

\subsubsection{Built-up}

The built-up of the study area converted to farmland represents $0.064 \%$ and $1.133 \%$ to sandy land, and $0.00011 \%$ to waterbody of the territory built-up along the study area; which was significantly advanced by $365.52 \%$ in 2018 . However, this 
expansion represents $4.96 \%$ of the built-up area; however, this indicates an advancement of built-up areas in this period.

\subsection{Discussion}

Ma'rib city lodges high population with major populations of agricultures and farmers. The area hosts the main dam of the Sahara of Yemen with agriculture capacities. It represents the major agricultural and economic resources of the Ar-Rub' AlKhali area. That is why this area is presented by a high level of dynamicity acting that has been accelerated by man-made processes and resulted in vital landform transformations in response to the current local economy especially after the war crisis.

The conversion matrix of land use land cover change from 1987 to 2001 (unit: pixel)

\begin{tabular}{|c|c|c|c|c|c|}
\hline $\begin{array}{c}\text { Class } \\
\mathbf{2 0 0 1}\end{array}$ & waterbody & $\begin{array}{c}\text { Cuild-up- } \\
\text { area }\end{array}$ & farmland & sandy land & Sum \\
\hline Waterbody & 14091 & 0 & 0 & 96 & 14187 \\
\hline build-up-area & 0 & 835 & 422 & 2691 & 3948 \\
\hline Farmland & 2650 & 365 & 18704 & 52393 & 74112 \\
\hline sandy land & 5938 & 1752 & 7840 & 742172 & $\mathbf{7 5 7 7 0 2}$ \\
\hline Sum & $\mathbf{2 2 6 7 9}$ & $\mathbf{2 9 5 2}$ & $\mathbf{2 6 9 6 6}$ & $\mathbf{7 9 7 3 5 2}$ & $\mathbf{8 4 9 9 9}$ \\
\hline
\end{tabular}

The conversion matrix of land use land cover change from 1987 to 2001 (unit :\%)

\begin{tabular}{|c|c|c|c|c|}
\hline $\begin{array}{c}\text { Class } \\
\text { 2001 }\end{array}$ & waterbody & $\begin{array}{c}\text { Cuild-up- } \\
\text { area }\end{array}$ & farmland & $\begin{array}{c}\text { sandy } \\
\text { land }\end{array}$ \\
\hline waterbody & 1,65 & 0 & 0 & 0,011 \\
\hline build-up-area & 0 & 0,098 & 0,049 & 0,31 \\
\hline farmland & 0,31 & 0,042 & 2,2006 & 6,16 \\
\hline sandy land & 0,69 & 0,206 & 0,92 & 87,31 \\
\hline
\end{tabular}

\begin{tabular}{|c|c|c|c|c|}
\hline $\mathrm{T}_{\mathrm{g}}=\frac{\mathrm{S}_{2}-\mathrm{S}_{1}}{\mathrm{~S}_{1}} \times 100$ & $-37,45 \%$ & $33,74 \%$ & $174,83 \%$ & $-4,97 \%$ \\
\hline$T_{c}=\frac{\ln s_{2}-\ln s_{1}}{\left(t_{2}-t_{1}\right) \ln e} \times 100$ & $-3,35 \%$ & $2,07 \%$ & $7,22 \%$ & $-0,36 \%$ \\
\hline
\end{tabular}

Table 1: Quantitative evaluation of land use changes during the period from 1987 to 2001.
The conversion matrix of land use land cover change from 2001 to 2011 (unit: pixel)

\begin{tabular}{|c|c|c|c|c|c|}
\hline $\begin{array}{c}\text { Class } \\
2011 \\
2001\end{array}$ & waterbody & $\begin{array}{l}\text { build-up- } \\
\text { area }\end{array}$ & farmland & $\begin{array}{c}\text { sandy } \\
\text { land }\end{array}$ & total \\
\hline waterbody & 30242 & 41 & 0 & 2488 & 32771 \\
\hline build-up-area & 32 & 11034 & 14820 & 66364 & 92250 \\
\hline farmland & 43036 & 7458 & 336165 & 383102 & 769761 \\
\hline sandy land & 54373 & 16999 & 315957 & 6351982 & 6739311 \\
\hline total & 127683 & 35532 & 666942 & 6803936 & 7634093 \\
\hline
\end{tabular}

The conversion matrix of land use land cover change from 2001 to 2011 (unit :\%)

\begin{tabular}{|l|c|c|c|c|}
\hline $\begin{array}{c}\text { Class } \\
\text { 2001 Class }\end{array}$ & waterbody & $\begin{array}{l}\text { build-up- } \\
\text { area }\end{array}$ & Farmland & $\begin{array}{l}\text { sandy } \\
\text { land }\end{array}$ \\
\hline waterbody & 0,39 & 0,00053 & 0 & 0,032 \\
\hline build-up-area & 0,00041 & 0,144 & 0,19 & 0,86 \\
\hline farmland & 0,56 & 0,097 & 4,403 & 5,018 \\
\hline sandy land & 0,71 & 0,22 & 4,138 & 83,20 \\
\hline
\end{tabular}

\begin{tabular}{|c|c|c|c|c|}
\hline$T_{g}=\frac{S_{2}-S_{1}}{S_{1}} \times 100$ & $-74,33 \%$ & $159,62 \%$ & $15,41 \%$ & $-0,94 \%$ \\
\hline$T_{c}=\frac{\ln s_{2}-\ln s_{1}}{\left(t_{2}-t_{1}\right) \ln e} \times 100$ & $-43,60 \%$ & $9,54 \%$ & $1,43 \%$ & $-0,09 \%$ \\
\hline
\end{tabular}

Table 2: Quantitative evaluation of land use changes during the period from 2001 to 2011. 
The conversion matrix of land use land cover change from 2011 to 2018 (unit: pixel)

\begin{tabular}{|c|c|c|c|c|c|}
\hline $\begin{array}{c}\text { Class } \\
2018 \text { Class }\end{array}$ & waterbody & $\begin{array}{c}\text { to } \\
\text { build-up- } \\
\text { area }\end{array}$ & farmland & $\begin{array}{c}\text { sandy } \\
\text { land }\end{array}$ & total \\
\hline Waterbody & 322696 & 0 & 0 & 52 & 32748 \\
\hline build-up-area & 0 & 70116 & 0 & 53579 & 123695 \\
\hline Farmland & 0 & 0 & 769761 & 260389 & 1030150 \\
\hline sandy land & 75 & 22135 & 0 & 6427219 & 6449429 \\
\hline Total & 32771 & 92251 & 769761 & 6741239 & 7636022 \\
\hline
\end{tabular}

The conversion matrix of land use land cover change from 2011 to 2018 (unit :\%)

\begin{tabular}{|c|c|c|c|c|}
\hline $\begin{array}{c}\text { Class } \\
2018\end{array}$ & Waterbody & build-up-area & farmland & sandy land \\
\hline Waterbody & 4,22 & 0 & 0 & 0,00068 \\
\hline build-up-area & 0 & 0,918 & 0 & 0,701 \\
\hline Farmland & 0 & 0 & 10,08 & 3,41 \\
\hline sandy land & 0,00098 & 0,28 & 0 & 84,16 \\
\hline
\end{tabular}

\begin{tabular}{|c|c|c|c|c|}
\hline$T_{g}=\frac{S_{2}-S_{1}}{S_{1}} \times 100$ & $-0,07 \%$ & $34,08 \%$ & $33,82 \%$ & $-4,32 \%$ \\
\hline$T_{c}=\frac{\ln s_{2}-\ln s_{1}}{\left(t_{2}-t_{1}\right) \ln e} \times 100$ & $-0,01 \%$ & $4,19 \%$ & $4,16 \%$ & $-0,63 \%$ \\
\hline
\end{tabular}

Table 3: Quantitative evaluation of land use changes during the period from 2011 to 2018
The conversion matrix of land use land cover change from 1987

\begin{tabular}{|c|c|c|c|c|c|}
\hline $\begin{array}{c}\text { to } 2018 \text { (unit: pixel) } \\
\text { Class } \\
\begin{array}{c}\text { Class } \\
1987\end{array}\end{array}$ & waterbody & $\begin{array}{c}\text { build-up- } \\
\text { area }\end{array}$ & farmland & $\begin{array}{c}\text { sandy } \\
\text { land }\end{array}$ & total \\
\hline waterbody & 30170 & 9 & 0 & 2569 & 32748 \\
\hline build-up-area & 114 & 11376 & 7569 & 104636 & 123695 \\
\hline farmland & 70852 & 4958 & 159511 & 794829 & 1030150 \\
\hline sandy land & 102975 & 10225 & 75581 & 6258709 & 6447490 \\
\hline total & 20411 & $\mathbf{2 6 5 6 8}$ & $\mathbf{2 4 2 6 6 1}$ & $\mathbf{7 1 6 0 7 4 3}$ & $\mathbf{7 6 3 4 0 8 3}$ \\
\hline
\end{tabular}

The conversion matrix of land use land cover change from 1987 to 2018 (unit :\%)

\begin{tabular}{|c|c|c|c|c|}
\hline $\begin{array}{c}\text { Class } \\
2018 \quad \text { wass } \\
1987\end{array}$ & waterbody & build-up-area & farmland & $\begin{array}{c}\text { sandy } \\
\text { land }\end{array}$ \\
\hline waterbody & 0,39 & 0,00011 & 0 & 0,033 \\
\hline build-up-area & 0,0014 & 0,149 & 0,0991 & 1,37 \\
\hline farmland & 0,928 & 0,064 & 2,089 & 10,41 \\
\hline Sandy land & 1,34 & 0,133 & 0,99 & 81,98 \\
\hline
\end{tabular}

\begin{tabular}{|c|c|c|c|c|}
\hline$T_{g}=\frac{S_{2}-S_{1}}{S_{1}} \times 100$ & $-83,95 \%$ & $365,52 \%$ & $324,52 \%$ & $-9,96 \%$ \\
\hline$T_{c}=\frac{\ln s_{2}-\ln s_{1}}{\left(t_{2}-t_{1}\right) \ln e} \times 100$ & $-5,90 \%$ & $4,96 \%$ & $4,66 \%$ & $-0,33 \%$ \\
\hline
\end{tabular}

Table 4: Quantitative evaluation of land use changes during the period from 1987 to 2018 


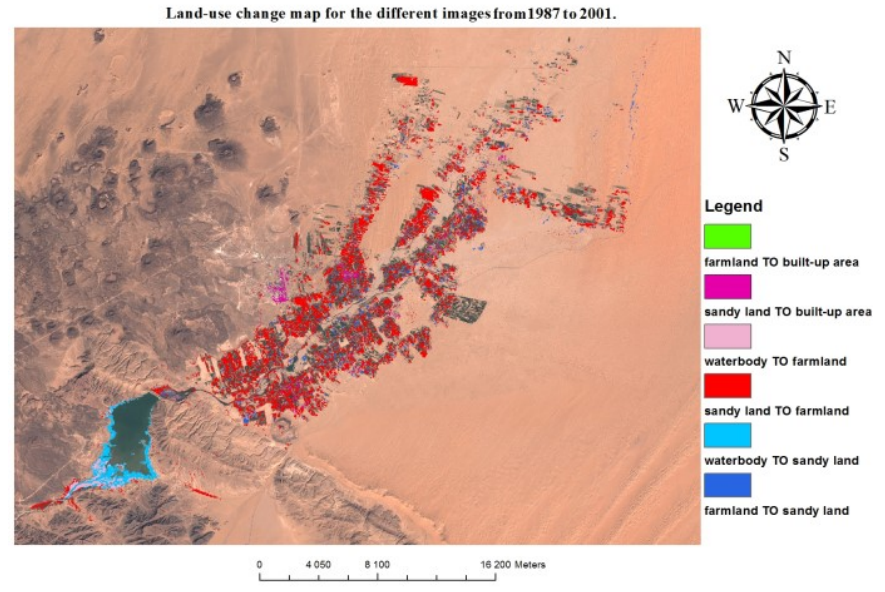

Fig.4. Geospatial distribution of LULC changes between 1987 and 2001.

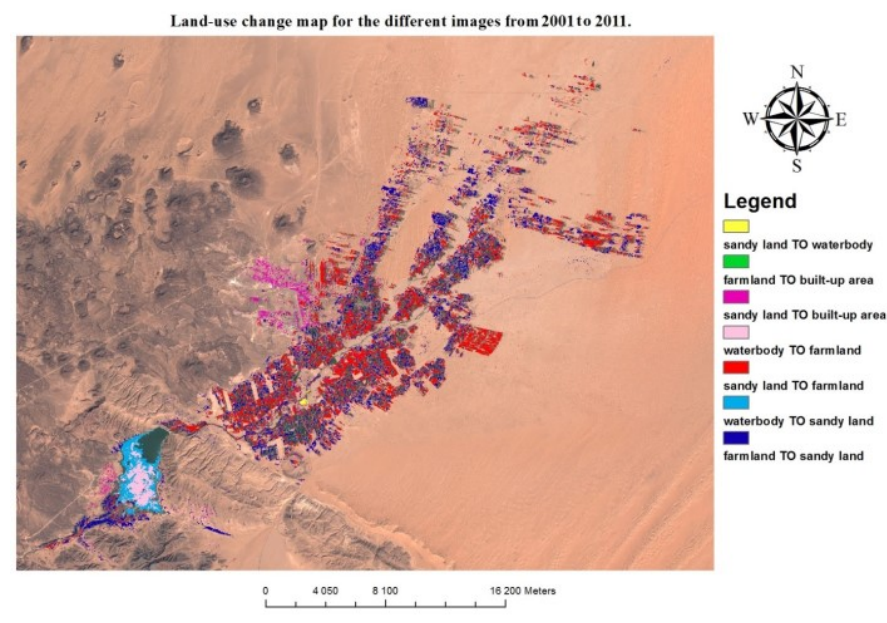

Fig.5. Geospatial distribution of LULC changes between 2001 and 2011 .

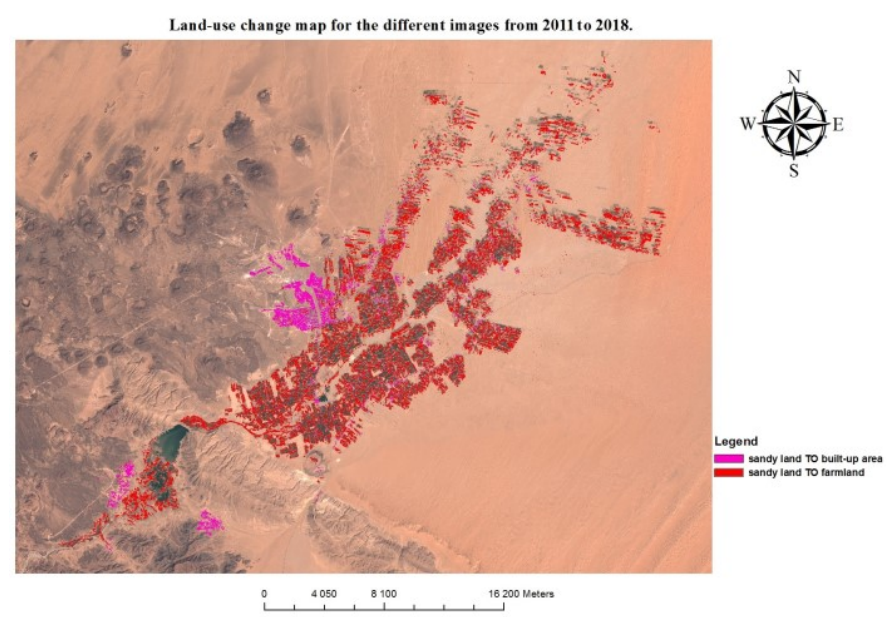

Fig.6. Geospatial distribution of LULC changes between 2011 and 2018

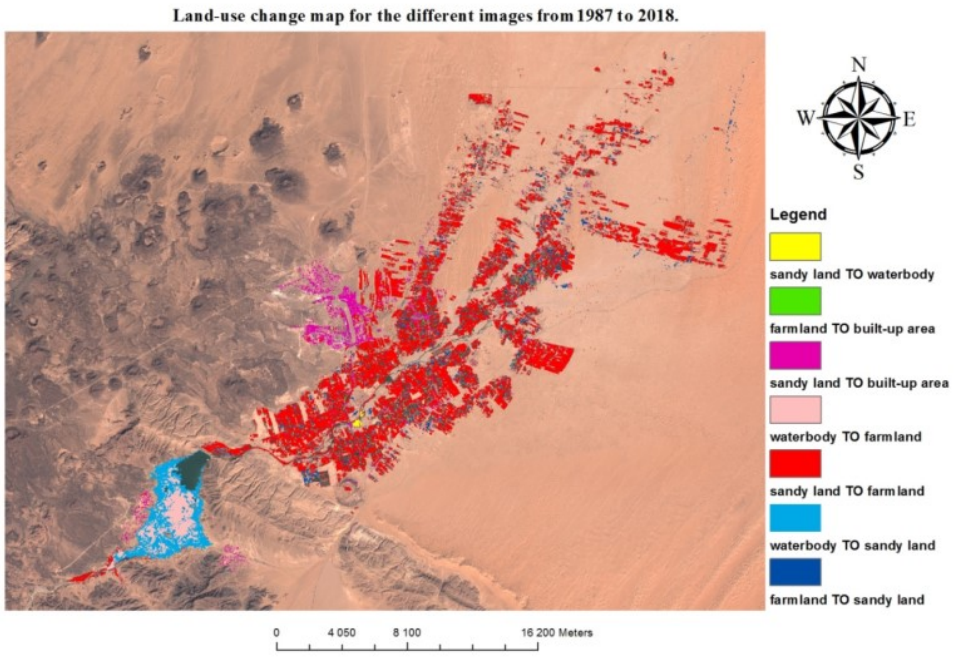

Fig.7. Geospatial distribution of LULC changes between 1987 and 2018

\section{CONCLUSIONS}

The city Ma'rib is experiencing a land use, land cover transformation that is mainly controlled by man-made activities which happened in response to either social or economic trends as well as the war trends, the immigration of populations or both. These changes will certainly impact the city not only by reshaping the spatial distribution of the current landforms but also will lead to a great change in the ecosystem of the study area such as modification/transformation of some land cover that exist along the study area. It is hence, recommended that this highly dynamic city requires accurate and continuous monitoring systems that enable regular delineation of the negative consequences of human alternation. Hence, it is recommended to undertake this at short, medium and long term scales to allow developing on-time responses and mitigation measures. The results showed an increase in land reclamation and cultivation, accompanied by an increase in the number of buildings.

\section{REFERENCES}

Abuelgasim, A.A., Ross, W.D., Gopal, S., Woodcock, C.E., 1999.

Change detection using adaptive fuzzy neural networks: environmental damage assessment after the Gulf War. Remote Sens. Environ. 70, 208-223.

Adeel, M., 2010. Methodology for identifying urban growth potential using land use and population data: a case study of Islamabad Zone IV. Procedia Environ. Sci. 1, 32-41.

Afify, H.A., 2011. Evaluation of change detection techniques for monitoring landcover changes: a case study in new Burg ElArab area. Alexandria Eng. J. 50, 187-195. 
Ahmad, A., 2012. Analysis of maximum likelihood classification on multispectral data. Appl. Mathemat. Sci. 6 (129), 6425-6436.

Ahmed, A., 2011. Some of the major environmental problems relating to land use changes in the coastal areas of Bangladesh. J. Geogr. Reg. Plan. 4, 1-8.

Akbari, M., Mamanpoush, A.R., Gieske, A., Miranzadeh, M., Torabi, M., Salemi, H.R., 2006.

Crop and land cover classification in Iran using Landsat 7 imagery. Inter. J. Rem. Sen. 27 (19), 4117-4135.

Alam, S.M.N., Demaine, H., Phillips, M.J., 2002. Landuse diversity in south western coastal areas of Bangladesh. The Land. 63, 173-184.

Alphan, H., 2003. Land-use change and urbanization of Adana, Turkey. Land Degrad. Dev. 14 (6), 575-586.

Amin, A., Fazal, S., 2012. Land transformation analysis using remote sensing and gis techniques (A Case Study). J. Geograph. Inform. Syst. 4, 229-236.

Anderson, J.F., Hardy, E.E., Roach, J.T., Witmer, R.E., 1976.

A land use and land cover classification system for use with remote sensor data. U.S. Geological Survey Professional Paper 964, U.S. Geological Survey, pp. 28-32.

Washington DC, USA. Aspinall, R.J., Hill, M.J., 1997. Land cover change: a method for assessing the reliability of land cover changes measured from remotely-sensed data. Proc. Geosci. Remote Sens. Sympos., 269-271 Vol. I-IV.

Atkinson, P.M., Cutler, M.E.J., Lewis, H., 1997. Mapping subpixel proportional land cover with AVHRR imagery. Inter. J. Rem. Sen. 18 (4), 917-935.

Avery, T.E., Berlin, G.L., 1992. Fundamentals of Remote Sensing and Airphoto Interpretation, fifth ed. MacMilan Publishing Company, New York, pp. 127-142.

Ayad, Y.M., 2004. Remote sensing and GIS in modeling visual landscape change: a case study of the northwestern arid coast of Egypt. Landsc. Urban Plan. 73, 307-325.

Baby, S., 2015. Monitorig the coastal land use land cover changes (LULCC) of Kuwait from spaceborne Landsat sensors. Indian J. Geo-Mar. Sci. 44 (6), 1-7.

Baraldi, A., Bruzzone, L., Blonda, P., 2005. Quality assessment of classification and cluster maps without ground truth knowledge. IEEE T. Geosci. Remote. 43, 857-873.

Benoit, M., Lambin, E.F., 2000. Land-cover-change Trajectories in Southern Cameroon. Ann. Assoc. Am. Geogr. 90 (3), 467-494.

Bhatta, B., Saraswati, S., Bandyopadhyay, D., 2010. Urban sprawl measurement from remote sensing data. Appl. Geogr. 30, $731-740$

Biging, G.S., Colby, D.R., Congalton, R.G., 1998. Sampling systems for change detection accuracy assessment, remote sensing change detection. In: Lunetta, R.S., Elvidge, C.D. (Eds.), Environmental Monitoring Methods and Applications.
Ann Arbor Press, Chelsea, Michigan, pp. 281-308. Boschetti, L., Flasse, S.P., Brivio, P.A., 2004. Analysis of the conflict between omission and commission in low spatial resolution dichotomic thematic products: the Pareto Boundary. Remote Sens. Environ. 91, 280-292.

Bradley, B.A., 2009. Accuracy assessment of mixed land cover using a GIS-designed sampling scheme. Int. J. Remote Sens. 30 (13), 3515-3529.

Brown, J.F., Loveland, T.R., Ohlen, D.O., Zhu, Z., 1999. The global land-cover characteristics database: the user's perspective. Photogramm. Eng. Rem. S. 65, 1069-1074.

Bruzzone, L., Cossu, R., Vernazza, G., 2004. Detection of landcover transitions by combining multidate classifiers. Pattern Recogn. Lett. 25, 1491-1500.

Butt, A., Shabbir, R., Ahmad, S.S., Aziz, N., 2015a. Land use change mapping and analysis using Remote Sensing and GIS: a case study of Simly watershed, Islamabad, Pakistan. Egypt. J. Rem. Sens. Space Sci. 18, 251-259.

Butt, A., Shabbir, R., Ahmad, S.S., Aziz, N., Nawaz, M., Shah, M.T.A., 2015b. Land cover classification and change detection analysis of Rawal watershed using remote sensing data. J. Biol. Environ. Sci. 6 (1), 236-248.

Carlotto, M.J., 2009. Effect of errors in ground truth on classification accuracy. Int. J. Remote Sens. 30, 4831-4849.

Central Ground Water Board (CGWB), 2008. District Groundwater Brochure, Kanyakumari District, Tamil Nadu Technical Report Series, Central Ground Water Board, South Eastern Coastal Region, Chennai, pp. 1-22.

Chandramohan, P., Sanil Kumar, V., Nayak, B.U., 1993. Coastal processes along the shorefront of Chilka lake, east coast of India. Indian J. Marine Sci. 22, 268-272.

Chandrasekar, N., 2005. Tsunami of 26th December 2004: observation on inundation, sedimentation and geomorphology of Kanyakumari Coast, South India. Proceeding of the 22nd IUGG Int. Tsunami Symp, Chania, Greece, pp. 49- 56.

Chandrasekar, N., Cherian, A., Rajamanickam, M., Rajamanickam, G.V., 2000. Coastal landform mapping between Tuticorin and Vaippar using IRS-IC data. Indian J. Geomorphol. 5 (1\&2), 115-122.

Chandrasekar, N., Cherian, A., Rajamanickam, M., Rajamanickam, G.V., 2001. Influence of Garnet sand mining on beach sediment dynamics between the Periathali and Navaladi coast, India. India. J. Indian Assoc Sedimentol. 20 (2), 223233.

Chandrasekar, N., Joevivek, V., Saravanan, S., 2013. Coastal vulnerability and shoreline changes for southern tip of IndiaRemote sensing and GIS approach, Earth Sci. Clim. Change. doi: $10.4172 / 2157-761711000144$

Chauhan, H.B., Nayak, S., 2005. Land use/land cover changes near Hazira region, Gujarat using remote sensing satellite data. J. Indian Soc. Remote. 33 (3), 413-420.

Chaurasia, R., Closhali, D.C., Dhaliwal, S.S., Minakshi, P.K.Sharma, Kudrat, M., Tiwari, A.K., 1996. Landuse change analysis for agricultural management - a case study of Tehsil 
Talwandi Sabo. Punjab. J. Indian Soc. Remote. 24 (2), 115123.

Chen, J., Gong, P., He, C., Pu, R., Shi, P., 2003. Land-use/landcover change detection using improved change-vector analysis. Photogramm. Eng. Rem. S. 69, 369-379.

Cherian, A., Chandrasekar, N., Gujar, A.R., Rajamanickam, V., 2012. Coastal erosion assessment along the southern Tamil Nadu coast. India. Int. J. Earth Sci. Eng. 5 (2), 352-357.

Chilar, J., 2000. Land cover mapping of large areas from satellites: status and research priorities. Int. J. Remote Sens. 21 (67), 1093-1114

Choudhary, R., Gowthaman, R., Sanil Kumar, V., 2013. Shoreline change detection from Karwar to Gokarna-South West coast of India using remotely sensed data. Int. J. Earth Sci. Eng. 6 (3), 489-494.

Clark, D., 1982. Urban Geography: an Introductory Guide. Croom Helm, London, pp. 200-220.

Congalton, R.G., Green, K., 1999. Assessing the Accuracy of Remotely Sensed Data: principles and Practices, CRC Press. Taylor \& Francis Group, Boca Raton, FL, pp. 159-171.

Coppin, P., Bauer, M.E., 1996. Digital change detection in forest ecosystems with remote sensing imagery. Remote Sens. Rev. 13, 207-234.

Coppin, P., Jonckheere, I., Nackaerts, K., Muys, B., 2004. Digital change detection methods in ecosystem monitoring: a review. Int. J. Remote Sens. 25 (9), 1565-1596.

Daily, G.C., 1995. Restoring value to the world's degraded lands. Science $269,350-354$.

Dewidar, K.M., Frihy, O.E., 2010. Automated techniques for quantification of beach change rates using Landsat series along the North-eastern Nile delta. Egypt. J. Oceanogr. Mar. Sci. 2, $28-39$.

Di Gregorio, A., Jansen, L.J.M., 2000. Land Cover Classification System. Classification concepts and user manual. Software version 1. FAO, Rome, Italy, pp. 179-192.

Dwivedi, R.S., Sreenivas, K., Ramana, K.V., 2005. Landuse/land-cover change analysis in part of Ethiopia using Landsat Thematic Mapper data. Int. J. Remote Sens. 26, 12851287.

El Asmar, H.M., Hereher, M.E., 2011. Change detection of the coastal zone east of the Nile Delta using remote sensing. Environ. Earth Sci. 62, 769-777.

El Gammal, E.A., Salem, S.M., El Gammal, A.E.A., 2010. Change detection studies on the world's biggest artificial lake (Lake Nasser, Egypt). Egypt. J. Rem. Sens. Space Sci. 13, 8999.

El-Asmar, H.M., Hereher, M.E., El Kafrawy, S.B., 2013. Surface area change detection of the Burullus Lagoon, North of the Nile Delta, Egypt, using water indices: a remote sensing approach. Egypt. J. Rem. Sens. Space Sci. 16, 119-123.

Foody, G.M., 2002. Status of land cover classification accuracy assessment. Remote Sens. Environ. 80 (1), 185-201.
Foody, G.M., 2010. Assessing the accuracy of land cover change with imperfect ground reference data. Remote Sens. Environ. 114, 2271-2285.

Foody, M.G., Mathur, A., 2004. A relative evaluation of multiclass image classification by support vector machines. IEEE Trans. Geosci. Remote Sens. 42, 1335-1343.

Foody, G.M., McCulloch, M.B., Yates, W.B., 1995. The effect of training set size and composition on artificial neural network classification. Int. J. Remote Sens. 16, 1707-1723.

Foody, G.M., Arora, M.K., 1997. An evaluation of some factors affecting the accuracy of classification by an artificial neural network. Int. J. Remote Sens. 18, 799-810.

Gibson, P.J., Power, C.H., 2000. Introductory Remote Sensing: digital Image Processing and Applications. Routledge, London, pp. 190-210.

Haque, A., Alam, J.B., Shaha, N.K., Raihan, F., 2008. Study on land use pattern change and its causes. Int. J. Environ. Res. 2, 199-204.

Hazarika, N., Das, A.K., Borah, S.B., 2015. Assessing land-use changes driven by river dynamics in chronically flood affected Upper Brahmaputra plains, India, using RS-GIS techniques. Egypt. J. Rem. Sens. Space Sci. 18, 107-118.

Hentry, C., Chandrasekar, N., Saravanan, S., Sahayam, D.J., 2010. Influence of geomorphology and bathymetry on the effects of the 2004 tsunami at Colachel, South India. B. Eng. Geol. Environ. 69, 431-442.

Monitoring urban growth and land use change detection with GIS and remote sensing techniques in Daqahlia governorate Egypt Ibrahim Rizk Hegazy , Mosbeh Rashed Kaloop ,13 February 2015

Archaeological remote sensing in Yemen, the Jabali test site From large-scale survey to field investigation, Jul 29, 2015.

Archaeopedological analyses around a Neolithic hearth and the beginning of Sabaean irrigation in the oasis of Ma'rib (Ramlat as-Sab'atayn, Yemen) Journal of Archaeological Science 37 ,2010, 1305-1310

Bruggemann, H.Y. (Ed.), 1997. Agro-Climatic Resources of Yemen. FAO/Agriculture Research Authority, Dhamar, p. 121.

Using remote sensing and GIS to detect and monitor land use and land cover change in Dhaka Metropolitan of Bangladesh during 1960-2005, Environ Monit Assess (2009) 150:237-249

Land use and land cover change detection in the western Nile delta of Egypt using remote sensing data, Applied Geography 31,2011 .

Coppin, P., Jonckheere, I., Nackaerts, K., Muys, B., \& Lambin, E. (2004). Digital change detection methods in ecosystem monitoring: a review. International Journal of Remote Sensing, 25(9), 1565e1596.

Warner, T. A., \& Campagna, D. J. (2009). Remote sensing with IDRISI Taiga: A beginner's guide. Hong Kong: Geocarto International Centre. 